\title{
ARTIST OF THE ENVIRONMENT: FREDERICK LAW OLMSTED
}

\section{Virginia Fitzpatrick}

Most works of art are shown to students in a visual dark-room with slidespresentation. Art educators talk about tactile qualities, but they seldom have opportunities to permit first-hand, tactile observations. One form of art that is created to be totally experienced is landscape architecture. Examples of environmental design are found in every large city and their easy access provides endless, and changing, examples of texture, color, space, shape, line, and composition -- a truly kinetic art form.

Parks have been part of human experience for thousands of years. There are references to "Hanging Gardens" in Babylon and gardens around and upon the palaces and ziggurats of Mesopotamia. The Persian hunting parks or "paradises" fascinated Greeks. Remains of early landscape architecture can be found at the mortuary temple of Queen Hatshepsut, at Deir-el-Bahari in Egypt, built about 1500 B.C.

During the early years of American history, parks were small, private, garden-like expanses that provided environmental pleasure to the owners and their friends. It was not until the 19th century that Americans felt the need to provide the tranquility and renewing powers they saw in nature, to the general public. The first public American park designed for the varied needs of thousands of people was Central Park in New York City. It was designed by Calvert Vaux and Frederick Law Olmsted in 1857. It was in reference to their work on Central Park that the term, landscape architect, came into common use. Since then the criteria for the discipline of landscape architecture has been largely determined by writings of Olmsted who is called America's first Landscape Architect. Olmsted's strongly voiced opinions about the structure and philosophy of public parks created the models for most of the city, state, and national parks in the United States. The reputation of Central Park "sparked a National Park movement which still comprises a substanial contribution to the United States economy" (Tobey, 1973). Later landscape architecture work by Olmsted included designs of parks in Yosemite, Boston, Brooklyn, Chicago and sixteen other cities. He also designed the grounds surrounding the United States Capitol and the grounds of twelve colleges and universities.

My research covers Olmsted's design work in three Louisville, Kentucky city parks during 1891-94. For the purpose of this paper, I will summarize that contribution and also comment on Olmsted's development of a landscape architecture curriculum, and his philosophy as an artist and aesthetician.

Frederick Law Olmsted was born in 1822 and raised in Hartford, Connecticut. His early years were spent in a rather carefree and unstructured way that was typical of an indulged son of a wealthy American businessman. Later he attended some classes at Yale, but never attempted to obtain a degree. He travelled in Europe, and sailed to the Orient as an apprentice seaman. He farmed in Connecticut and Staten Island, wrote articles for newspapers, and magazines, wrote five books and worked for the government during the Civil War as General 
Secretary of the Sanitary Commission. After the war, at the age of forty, and after designing Central Park, Olmsted finally recognized that his interst in, and his knowledge of, landscape design could lead to a permanent career.

Olmsted's aesthetic philosophy reflected his cultre. It was a time when intellectual Americans turned to nature as "perfect beauty" which had redemptive and soothing qualities. It was the time of Hudson River painters, and writers such as Thoreau. Long before Herbert Read, and Henry Turner Bailey spoke of art as a source of beauty and morality, New England Transcendentalists were extolling the beauty of nature as a source for inspiration and moral improvement.

Olmsted's parks are our most easily accessible surviving examples of these 19th century ideals of beauty. They parallel industrial growth and were a salve to the conscience of industrialists who promoted their development for the physical and psychical comfort of the over-worked and under-nourished employees who lived in dirty and crowded inner-city housing. Olmsted did not turn his back on materialism as did Thoreau, but rather sought to change the environment - to provide temporary relief within the beauty of nature. His belief in the healing powers of nature explains his insistence that every city needed parks and that these areas be designed to represent as natural a setting as possible - close to, and easily accessible to crowded inner city dwellings.

Acknowledging the inherent politics of establishing parks and the "bottom line" of those would pay for them, Olmsted frequently remarked that parks increased the property values of surrounding land.

Like Beaux Arts architects, he tried to stamp the city with an ennobling vision - his parks were deisnged to be elegant, elevating, and educational. They were conceived primarily as a visual experience, (with carefully) laid out pathways and carriage ways with a series of vantage points for enjoying the park's carefully arranged landscape compositions (Barlow, 1972).

The three largest parks in Louisville still reflect Olmsted's design philosophy. Each of the parks has a unique character which he preserved. In recognition of Indian tribes thought to have lived in the area, the parks were named, Shawnee, Iroquois, and Cherokee. Shawnee Park is in a flat area, bordered on one side by the Ohio River. Olmsted left large, open spaces in the center of 181 acres, and trees are clustered around the edges to give visitors a shaded resting place while they watch boats on the Ohio River or activities in the middle of park clearnings. Olmsted expressed a desire to only "make improvements by design which nature might make by chance" (Stevenson, 1977).

A contrast to Shawnee Park is obvious to visitors when they enter Iroquois Park's 676 acres. Park roads immediately wander uphill in deliberately circuitous routes through the forest to the top of the mountain and a scenic lookout. In typical Victorian style, Olmsted described Iroquois Park as "a treasure of sylvan scenery... (with) the grandeur of the forest depths in the dim seclusion of which (one) may wander musingly for hours. . . and from its upper parts fine, broad, distant prospects are to be had" (First Annual, 1891). 
The character of the third Louisville park designed by Frederick Law Olmsted is different from the first two. Cherokee Park is in a gently rolling area of 409 acres. It was covered with trees when Olmsted first saw it in 1891. The wide creek running through it added to its beauty. In fact, Olmsted's recommendations included the comment that "to procure such scenery in higher perfection than. .. it is yet to be found in any public park in America, all that is needed is the removal of fences and a little judicious use of the ax (First Annual, 1891). He decided which trees to cut down and where to plant others to form "views" in the fashion of European parks and gardens of the 19th century. In 1974, a series of tornadoes ripped straight across this park, uprooting most of the trees Olmsted had suggested saving 80 years before. Olmsted's designs were obtained from the firm's former office in Brookline, Massachusetts and used to replant the park.

Olmsted's emphasis on environmental composition and texture and his concern for what he thought would provide a moral uplift to crowded tenement dwellers, and his desire to show only the beauty of nature, was typical of most artists in his time. His own artistic education was obtained from tutors, reading and European travels. He studied topographical engineering with Frederick Burton for two years and farmed in Connecticut and New York for 10 years. There were no schools or colleges for landscape architects at that time - and the field was practiced by nurserymen, engineers, gardeners, surveyors, and architects.

As his fame increased, many young men wrote to Olmsted asking for advice on how to become landscape architects.

The artistic inclination and fondness for gardens that some thought qualified them naturally for the profession, disqualified them in Olmsted's view, suggesting (that) they cared more for beautiful objects and scenes than for scenery in composition (Roper, 1973).

For those who were to work in his office, Olmsted recommended graduate courses in architecture and engineering, freehand and mechanical drawing, botany, and horticulture. . . independent study of good pictures, two to three years of apprenticeship in his office. .. travel at the students' own expense, and extensive assigned reading and a tour of foreign study - these prerequisites to beginning practice could consume 8 years after college. And all of this study was required at a time when there was no big demand for the services of landscape architects.

In January and February of 1895, at the end of his carrer, Olmsted began to plan a systematic course of training in every branch of landscape architecture to be given in his office. He commented, "We are gradually preparing a grand professional post-graduate school. .." (Roper, 1973). Two books that had influenced his choice of careers and became required reading for his students were Sir Uvedale Price's On the Picturesque, and William Gilpin's Forest Scenery, both written at the end of the 18th century (Barlow, 1972). Five years later, eleven landscape architects, most of them trained by Olmsted, met to form the first professional association of landscape architects, the American Society of Landscape Architects. The following year Harvard established the first university 
curriculum of professional training in landscape architecture.

The science and art of landscape architecture has been manifested in beautiful parks, and campuses and estates throughout our country for over 100 years. These areas of arranged nature are frequently close to our schools. As art educators we can use work of landscape architects as part of our lessons on art history, and general aesthetics. We can talk about the design of nature in parks as an art form - one in which we find sensory properties of texture, color, space and shapes, molded into a unity by carefully planned roads, walkways, contemplative areas and recreational spaces.

Landscape architecture provided a means for Frederick Law Olmsted to render a social service to help solve the problems of a changing nation at the same time he was creating beautiful parks. His parks are more than charming exercises in a quaint, old fashioned style known as the Picturesque. . . they represent a synthesis of service, and concern for aesthetics.

\section{REFERENCES}

Barlow, Elizabeth. Frederick Law Olmsted's New York. New York, New York: Praeger Publishers, 1972.

First Annual Report of the Board of Park Commissioners of the City of Louisville. Louisville, Kentucky: Courier-Journal Job Printing Company, 1891.

Louisville IV file, March 15, 1894, Olmsted Papers, Library of Congress.

Newton, Norman. Design on the Land. Cambridge: The Belknap Press of Harvard University Press, 1971.

Olmsted, Frederick Law Jr. Forty Years of Landscape Architecture - Frederick Law Olmsted Sr. Cambridge: Massachusetts Institute of Technology Press, 1928.

Roper, Laura Wood. FLO a Biography of Frederick Law Olmsted. Baltimore: The John Hopkins University Press, 1973.

Stevenson, Elizabeth. Park Maker: A Life of Frederick Law Olmsted. New York: Macmillan Publishing Company Inc., 1977.

Tobey, G. B. A History of Landscape Architecture. New York: American Elsevier Publishing Company, Inc., 1973. 